\title{
ANALYSIS OF THE EFFECTS OF TEMPERATURE, THE AMOUNT OF NUTRIENT SOLUTION AND THE CARBON DIOXIDE CONCENTRATION ON METHANE BIOFILTRATION
}

\author{
C. MENARD, A. AVALOS RAMIREZ, J. NIKIEMA \& M. HEITZ \\ Department of Chemical Engineering and Biotechnological Engineering, Faculty of Engineering, \\ Université de Sherbrooke, Québec, Canada.
}

\begin{abstract}
Landfill gas emissions contribute to the greenhouse effect due to the presence of methane $\left(\mathrm{CH}_{4}\right) \cdot \mathrm{CH}_{4}$ emissions from old and small landfills can be reduced by using biofiltration. The objective of this study was to optimize parameters that control $\mathrm{CH}_{4}$ removal in a biofilter. Temperature is one of the important parameters as well as the amount of nutrient solution (NS) supplied. The effects of the carbon dioxide $\left(\mathrm{CO}_{2}\right)$ concentration on $\mathrm{CH}_{4}$ biofiltration were also studied. Four biofilters using an inorganic filter bed were studied under similar conditions: an inlet $\mathrm{CH}_{4}$ concentration of $7000 \mathrm{ppmv}$ and an air flow rate of $0.25 \mathrm{~m}^{3} / \mathrm{h}$. A NS was supplied daily. The temperature was varied from $4^{\circ} \mathrm{C}$ to $43^{\circ} \mathrm{C}$. The highest performance was obtained in the range of $31-34^{\circ} \mathrm{C}$ with an elimination capacity (EC) of $30 \mathrm{~g} \mathrm{CH}_{4} / \mathrm{m}^{3} / \mathrm{h}$ for an inlet load (IL) of $80 \mathrm{~g} \mathrm{CH}_{4} / \mathrm{m}^{3} / \mathrm{h}$. The effect of the amount of NS supplied to the biofilter at ambient temperature was also analyzed. The EC was $23 \mathrm{~g} \mathrm{CH}_{4} / \mathrm{m}^{3} / \mathrm{h}$ for both $101 \mathrm{~L}_{\mathrm{NS}} / \mathrm{m}^{3} \mathrm{~V}$ bed $/ \mathrm{d}$ and $34 \mathrm{~L}_{\mathrm{NS}} / \mathrm{m}^{3} \mathrm{~V}$ bed $/ \mathrm{d}$, but it fell to $17 \mathrm{~g} \mathrm{CH}_{4} / \mathrm{m}^{3} / \mathrm{h}$ at $17 \mathrm{~L}_{\mathrm{NS}} / \mathrm{m}^{3} \mathrm{v}$ bed $/ \mathrm{d} . \mathrm{CO}_{2}$ concentrations were varied from 650 to $18,500 \mathrm{ppmv}$ and no effect was noticed on the EC which remained constant at $18 \mathrm{~g}$ $\mathrm{CH}_{4} / \mathrm{m}^{3} / \mathrm{h}$ for an inlet load of $72 \mathrm{~g} \mathrm{CH}_{4} / \mathrm{m}^{3} / \mathrm{h}$.

Keywords: air treatment, biofiltration, carbon dioxide, environment, methane, nutrient solution, temperature.
\end{abstract}

\section{INTRODUCTION}

Atmospheric methane $\left(\mathrm{CH}_{4}\right)$ concentrations have increased from 715 ppbv during the industrial revolution (19th century) to $1785 \mathrm{ppbv}$ in 2008 [1]. Up to $65 \%$ of emissions are due to anthropogenic sources such as fossil fuel combustion, agriculture, waste handling and rice cultivation [2]. $\mathrm{CH}_{4}$ is the second most important greenhouse gas, just after carbon dioxide $\left(\mathrm{CO}_{2}\right)$. Its global warming potential (GWP) is 25 times higher than the one for $\mathrm{CO}_{2}$, based on a 100-year time horizon [3]. Among the anthropogenic sources, landfills contributed to $20 \%$ of the $\mathrm{CH}_{4}$ emissions in Canada in 2007 [4], while the value was about $18 \%$ worldwide [5].

$\mathrm{CH}_{4}$ recovery from landfills tends to be developed in Canada and 65 gas extraction systems were installed in 2007 [4]. Recent studies from nine landfill cells in France have shown that 92-97\% of biogas can be recovered [6]. To achieve efficient energy valorization, $\mathrm{CH}_{4}$ concentrations higher than $30-40 \%(\mathrm{v} / \mathrm{v})$ are required with a minimum gas flow rate of $50 \mathrm{~m}^{3} / \mathrm{h}$ [7]. An alternative to energy valorization is flaring, which needs $\mathrm{CH}_{4}$ concentrations higher than $20 \%$ (v/v) and a flow rate of $15 \mathrm{~m}^{3} / \mathrm{h}$ to be economically feasible [7]. When concentrations and flow rates are no longer appropriate for energy valorization or flaring, biofiltration is a bioprocess well adapted to control $\mathrm{CH}_{4}$ emissions. It is generally the main control process for small and old landfills but it provides also a secondary treatment process for large and new landfills which have recovery installations [8].

Biofiltration is a triphasic biotechnology which uses microorganisms to eliminate pollutants like volatile organic compounds (VOC), volatile inorganic compounds (VIC) or greenhouse gases (GHGs) like $\mathrm{CH}_{4}$. The pollutant is transformed into water $\left(\mathrm{H}_{2} \mathrm{O}\right), \mathrm{CO}_{2}$, biomass and salts. The degradation process of $\mathrm{CH}_{4}$ is divided into three steps. First, $\mathrm{CH}_{4}$ is oxidized to methanol $\left(\mathrm{CH}_{3} \mathrm{OH}\right)$ by an enzyme called methane monooxygenase (MMO). Methanol is then transformed 
in formaldehyde $(\mathrm{HCHO})$. This intermediary product is used to generate $\mathrm{CO}_{2}, \mathrm{H}_{2} \mathrm{O}$ and biomass during the last step [9]. The bacteria responsible for $\mathrm{CH}_{4}$ oxidation are called methanotrophic bacteria and are part of the methylotrophic bacteria able to assimilate $\mathrm{C} 1 \mathrm{compounds}$ (like $\mathrm{CH}_{4}$ and methanol).

Engineered systems developed to optimize $\mathrm{CH}_{4}$ biooxidation in landfills are either biocovers or biofilters. Biocovers are generally spread over an entire landfill area or a specific sector while biofilters are defined as fixed bed reactors, filled with a packing material and provided with a gas collection and drainage system [8].

Several variables need to be taken into account to control the microbial $\mathrm{CH}_{4}$ oxidation such as the moisture content, temperature, oxygen availability, $\mathrm{CH}_{4}$ concentration and addition of nutrients. Since microbial metabolism is limited by temperature, this parameter is one of the most important. Mesophilic cultures of methanotrophic bacteria have an optimal range from $20^{\circ} \mathrm{C}$ to $37^{\circ} \mathrm{C}$ to live and multiply [10]. Methanotrophic bacteria tolerant to cold have their optimum temperature under $20^{\circ} \mathrm{C}$ [11] and the microorganisms are still active down to $1-2^{\circ} \mathrm{C} \mathrm{[12].} \mathrm{Labo-}$ ratory batch experiments have shown an optimal temperature range of $30-36^{\circ} \mathrm{C}$ and $25-35^{\circ} \mathrm{C}$ in landfill soil biocovers [13, 14]. Results from field investigations indicated a higher $\mathrm{CH}_{4}$ elimination for a temperature range from $9^{\circ} \mathrm{C}$ to $25^{\circ} \mathrm{C}$ than the range $2-9^{\circ} \mathrm{C}, 96 \%$ and $0-22 \%$, respectively, using mechanically biologically treated waste as a biocover [15]. In western Canada, $\mathrm{CH}_{4}$ conversion reached $33 \%, 55 \%$ and $89 \%$ in a landfill biocover, for respective minimal temperatures of $3{ }^{\circ} \mathrm{C}$ (unheated bed), $8^{\circ} \mathrm{C}$ (heated bed) and $12^{\circ} \mathrm{C}$ (heated and temperature controlled bed) [11].

Similarly, the moisture content influences the $\mathrm{CH}_{4}$ biooxidation rate as microorganisms require moisture to carry out their normal metabolic activity [16]. An optimal water level range should be sought for each filter material to prevent the drying-out of the filter bed or reversely, water clogging. The first event causes a significant reduction in the biodegradation rate while the second inhibits the transfer of oxygen and $\mathrm{CH}_{4}$ and promotes the development of anaerobic zones [17, 18]. Several studies have dealt with the optimal range of moisture for $\mathrm{CH}_{4}$ biofiltration using different filter beds. However, relatively few studies have analyzed the effect of the amount of nutrient solution (NS) supplied to the biofilter. According to our knowledge, one study was reported for toluene biofiltration, in a lab-scale fungal biofilter of $2.9 \mathrm{~L}$, where the watering flow rate was decreased from 344 $\mathrm{L}_{\mathrm{NS}} / \mathrm{m}^{3}{ }_{\mathrm{V} \text { bed }} / \mathrm{d}$ to $34 \mathrm{~L}_{\mathrm{NS}} / \mathrm{m}^{3}{ }_{\mathrm{V} \text { bed }} / \mathrm{d}$ and also interrupted for 5 days [19]. The effect of nutrient addition is also important. In fact, some filter beds already contain the necessary macro and micronutrients to maintain an adequate microbial population [20]. However, an extra-addition of NS is needed in certain cases, particularly for inorganic filter bed [21].

The $\mathrm{CO}_{2}$ concentration is not considered a key parameter for $\mathrm{CH}_{4}$ biofiltration. However, high concentrations of $\mathrm{CO}_{2}$ in the range from $30 \%$ to $65 \%(\mathrm{v} / \mathrm{v})$ are often reported in landfill gas emissions [6, 8]. Previous studies report diverging results. A reduction of $16-30 \%$ in $\mathrm{CH}_{4}$ uptake was observed in a forest soil continuously enriched with $\mathrm{CO}_{2}$ at 200 ppmv above ambient levels [22]. In a different study, no significant effect in the rates of $\mathrm{CH}_{4}$ oxidation was noticed for $\mathrm{CO}_{2}$ concentrations ranging from 400 to $400,000 \mathrm{ppmv}$ in laboratory experiments with landfill biocover [23]. However, the $\mathrm{CO}_{2}$ respiration rates decreased with the high $\mathrm{CO}_{2}$ concentrations.

The main objective of this study was to determine the optimal temperature range for $\mathrm{CH}_{4}$ elimination with an inorganic filter bed at a $\mathrm{CH}_{4}$ inlet concentration around 7000-7500 ppmv and a flow rate of $0.25 \mathrm{~m}^{3} / \mathrm{h}$. Two models to quantify the effect of the temperature were also tested. In addition, other experiments were performed to analyze the effect of the amount of NS supplied to the biofilter and the influence of $\mathrm{CO}_{2}$ above the atmospheric concentration at ambient temperature $\left(24^{\circ} \mathrm{C}\right)$. 


\section{MATERIALS AND METHODS}

\subsection{Experimental set-up}

The experimental set-up is shown in Fig. 1. The upflow laboratory-scale biofilter column is made of Plexiglas with an internal diameter of $0.15 \mathrm{~m}$. The biofilter is divided into three identical sections of $0.27 \mathrm{~m}$ high and was filled with an inorganic medium. Due to an existing confidentiality agreement, specific details about the characteristics of the filter bed are not available for publication at this time. The gas mixture is carried out at the bottom of the biofilter and consisted in mixing pre-humidified air and pure $\mathrm{CH}_{4}$ (Praxair Inc., Québec, Canada) in the desired concentration. The effluent gas is sent to an evacuation system.

\subsection{Operating conditions}

Experiments were carried out on two biofilters to evaluate the influence of the temperature. Both were operated under the same inlet air flow rate of $0.25 \mathrm{~m}^{3} / \mathrm{h}$ at a $\mathrm{CH}_{4}$ concentration around $7000-7500 \mathrm{ppmv}$. The initial temperature was fixed at $24^{\circ} \mathrm{C}$. After 20 days of operation, one biofilter (BFH) was covered with both a silicon heating unit and an aluminum thermal blanket to increase the temperature from $24^{\circ} \mathrm{C}$ to $43^{\circ} \mathrm{C}$. The second biofilter (BFL) was put into a temperature controlled chamber to decrease the temperature. Temperatures tested for $\mathrm{BFH}$ were $25^{\circ} \mathrm{C}, 31^{\circ} \mathrm{C}, 34^{\circ} \mathrm{C}, 41^{\circ} \mathrm{C}$ and $43^{\circ} \mathrm{C}$, and $25^{\circ} \mathrm{C}, 14^{\circ} \mathrm{C}$ and $4^{\circ} \mathrm{C}$ for BFL. The amount of NS was constant at $67 \mathrm{~L}_{\mathrm{NS}} / \mathrm{m}^{3} \mathrm{v}$ bed $/ \mathrm{d}$.

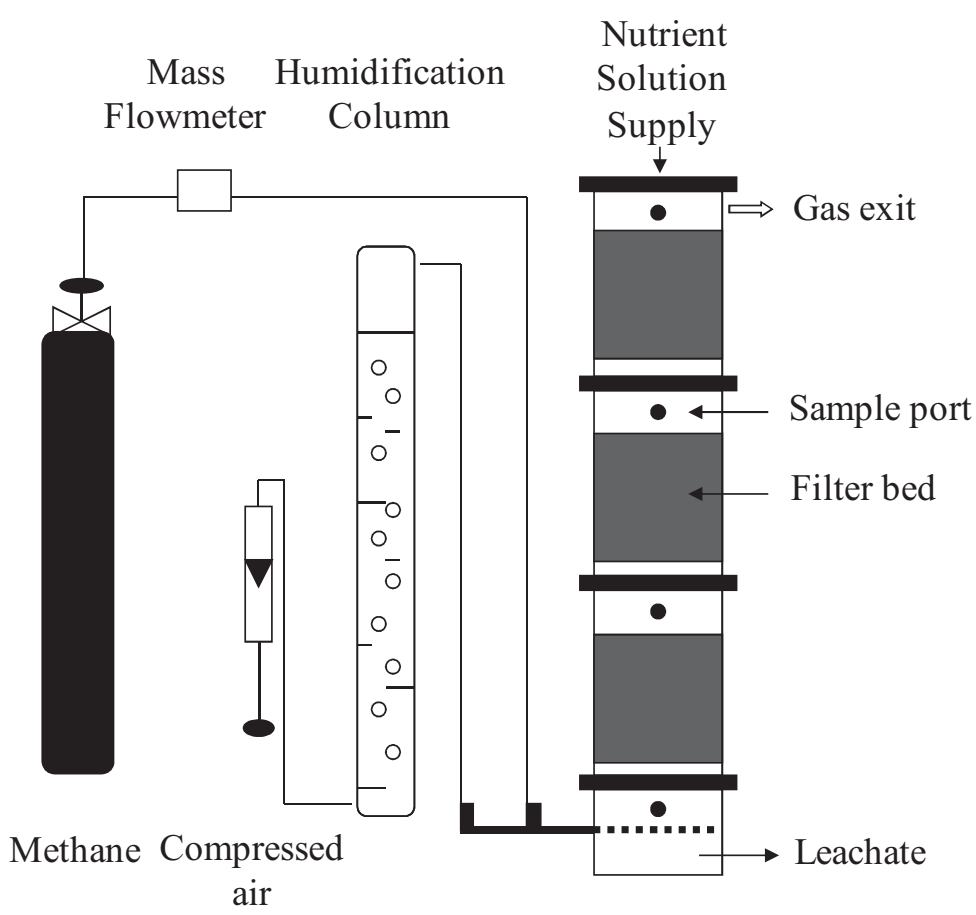

Figure 1: Laboratory-scale biofiltration system. 
A third biofilter (BFA) was used to evaluate the influence of the amount of NS supplied with an inlet air flow rate of $0.25 \mathrm{~m}^{3} / \mathrm{h}$ and at a $\mathrm{CH}_{4}$ concentration around $7000-7500 \mathrm{ppmv}$ at ambient temperature $\left(24^{\circ} \mathrm{C}\right)$. The amount of NS supplied ranged from $17 \mathrm{~L}_{\mathrm{NS}} / \mathrm{m}^{3}{ }_{\mathrm{V} \text { bed }} / \mathrm{d}$ to $101 \mathrm{~L}_{\mathrm{NS}} / \mathrm{m}^{3}{ }_{\mathrm{V} \text { bed }} / \mathrm{d}$.

$\mathrm{CO}_{2}$ concentrations were varied in a fourth biofilter (BFC) from 650 to $18,500 \mathrm{ppmv}$. BFC was operated at ambient temperature $\left(24^{\circ} \mathrm{C}\right)$ with an amount of $\mathrm{NS}$ of $67 \mathrm{~L}_{\mathrm{NS}} / \mathrm{m}^{3}{ }_{\mathrm{V} \text { bed }} / \mathrm{d}$. The detailed composition of the NS for macro and micronutrients is described in Table 1.

\subsection{Parameters for analyzing biofilter performance}

The performance of a biofilter is expressed in terms of the inlet load (IL) $\left(\mathrm{g} \mathrm{CH}_{4} / \mathrm{m}^{3} / \mathrm{h}\right.$ ), the elimination capacity (EC) $\left(\mathrm{g} \mathrm{CH}_{4} / \mathrm{m}^{3} / \mathrm{h}\right)$, the conversion rate $\mathrm{X}$ (non-dimensional) and the $\mathrm{CO}_{2}$ production rate $\mathrm{PCO}_{2}\left(\mathrm{~g} \mathrm{CO}_{2} / \mathrm{m}^{3} / \mathrm{h}\right)$ as shown below:

$$
\begin{gathered}
\mathrm{IL}=\frac{C_{\text {in }} * Q}{V_{\text {bed }}} \\
\mathrm{EC}=\frac{\left(C_{\text {in }}-C_{\text {out }}\right) * Q}{V_{\text {bed }}} \\
\mathrm{X}=\frac{C_{\text {in }}-C_{\text {out }}}{C_{\text {in }}} \\
\mathrm{PCO}_{2}=\frac{\left(C_{\mathrm{CO}_{2}{ }^{\prime} \text { out }}-C_{\mathrm{CO}_{2}{ }^{\prime} \text { in }}\right) * Q}{V_{\text {bed }}}
\end{gathered}
$$

where $Q$ is the total air flow rate $\left(\mathrm{m}^{3} / \mathrm{h}\right), V_{\text {bed }}$ is the packing bed volume $\left(\mathrm{m}^{3}\right), C_{\text {in }}$ is the $\mathrm{CH}_{4}$ inlet concentration $\left(\mathrm{g} / \mathrm{m}^{3}\right), C_{\text {out }}$ is the $\mathrm{CH}_{4}$ outlet concentration $\left(\mathrm{g} / \mathrm{m}^{3}\right), C_{\mathrm{CO} 2 \text {, in }}$ is the $\mathrm{CO}_{2}$ inlet concentration $\left(\mathrm{g} / \mathrm{m}^{3} / \mathrm{h}\right)$ and $C_{\mathrm{CO} 2 \text {,out }}$ is the $\mathrm{CO}_{2}$ outlet concentration $\left(\mathrm{g} / \mathrm{m}^{3} / \mathrm{h}\right)$.

The inlet and outlet $\mathrm{CH}_{4}$ concentrations present in the gas phase were measured by means of a FIA-510 total hydrocarbon analyzer (Horiba, USA). $\mathrm{CO}_{2}$ concentrations were analyzed with a

Table 1: Composition and concentration of the macro and micronutrient solution.

\begin{tabular}{lclc}
\hline Macronutrients & Concentration $(\mathrm{mg} / \mathrm{L})$ & Micronutrients & Concentration $(\mu \mathrm{g} / \mathrm{L})$ \\
\hline $\mathrm{NaNO}_{3}$ & 3038 & $\mathrm{ZnSO}_{4}, 7 \mathrm{H}_{2} \mathrm{O}$ & 576 \\
$\mathrm{~K}_{2} \mathrm{SO}_{4}$ & 170 & $\mathrm{MnSO}_{4}, 7 \mathrm{H}_{2} \mathrm{O}$ & 466 \\
$\mathrm{MgSO}_{4}, 7 \mathrm{H}_{2} \mathrm{O}$ & 37 & $\mathrm{H}_{3} \mathrm{BO}_{3}$ & 124 \\
$\mathrm{CaCl}_{2}, 2 \mathrm{H}_{2} \mathrm{O}$ & 7 & $\mathrm{NaMoO}_{4}, 2 \mathrm{H}_{2} \mathrm{O}$ & 96 \\
$\mathrm{KH}_{2} \mathrm{PO}_{4}$ & 530 & $\mathrm{CoCl}_{2}, 6 \mathrm{H}_{2} \mathrm{O}$ & 96 \\
$\mathrm{Na}_{2} \mathrm{HPO}_{4}$ & 860 & $\mathrm{KI}$ & 166 \\
& & $\mathrm{CuSO}_{4}, 5 \mathrm{H}_{2} \mathrm{O}$ & 250 \\
& & $\mathrm{FeSO}_{4}, 7 \mathrm{H}_{2} \mathrm{O}$ & 112 \\
\hline
\end{tabular}


portable gas analyzer system (Ultramat 22P, Siemens AG, Germany). The bed pressure drop was measured with a differential manometer (Type 4, Air Flow Developments Ltd., UK). The temperature inside the filter bed was monitored with T-type thermocouples (18G, Omega, USA). The moisture content of the filter bed was calculated by subtracting the mass of a sample of the filter bed before and after drying in an oven at $105^{\circ} \mathrm{C}$ and divided by the mass of the sample.

\subsection{Parameters for modeling the effect of the temperature}

Several models have been used to quantify the effect of the temperature on the growth of different microorganisms like Arrhenius or Esener. These models are based originally on the determination of microkinetic parameters such as the maximum specific growth rate $\left(\mu_{\max }\right)$ by batch experiments [24, 25].

To perform kinetic analysis in a biofilter, another approach has been considered, the macrokinetic approach, which is related to the pollutant biodegradation rate [26]. In this case, the kinetic parameters are defined with models based on the Michaelis-Menten approach. It has been shown that macrokinetic models fit well to the experimental EC [26-28].

In the present study, we used the macrokinetic approach in both the modified model of Arrhenius [29] and the model of Esener [30].

The modified Arrhenius equation is given below:

$$
E C=A \cdot e^{\left(-E_{a} / R T\right)}
$$

where $A$ is a pre-exponential factor $\left(\mathrm{g} / \mathrm{m}^{3} / \mathrm{h}\right), E_{a}$ is the activation energy for $\mathrm{CH}_{4}$ biodegradation $(\mathrm{kJ} / \mathrm{mol}), R$ is the universal gas constant $(\mathrm{kJ} / \mathrm{mol} / \mathrm{K})$ and $T$ is the absolute temperature $(\mathrm{K})$.

The second model is the modified Esener model [30]:

$$
E C=\frac{A^{\prime} \cdot e^{\left(-E_{1} / R T\right)}}{1+k \cdot e^{\left(-E_{2} / R T\right)}}
$$

where $A^{\prime}\left(\mathrm{g} / \mathrm{m}^{3} / \mathrm{h}\right)$ and $k$ (dimensionless) are both pre-exponential factors and $\mathrm{E}_{1}, \mathrm{E}_{2}$ are the activation energy for $\mathrm{CH}_{4}$ biodegradation and for the thermal denaturation processes $(\mathrm{kJ} / \mathrm{mol})$, respectively. The optimum temperature $\left(T_{o p t}\right)$ was calculated thanks to the following equation obtained by setting the first derivative of eqn (6) with respect to $T$ equal to zero:

$$
T_{\text {opt }}=\frac{E_{2}}{\left[R \cdot \ln \left(k \cdot\left(\frac{E_{2}}{E_{1}}-1\right)\right)\right]}
$$

\section{RESULTS AND DISCUSSION}

\subsection{Temperature experiments}

\subsubsection{Experimental results}

For the two biofilters BFH and BFL, the IL, the $\mathrm{PCO}_{2}$, the $\mathrm{EC}$ and temperature (T) as a function of time are presented in Figs 2 and 3. The IL was nearly constant during all the experiments with a mean value of $80 \pm 5 \mathrm{~g} \mathrm{CH}_{4} / \mathrm{m}^{3} / \mathrm{h}$ for the two biofilters. 


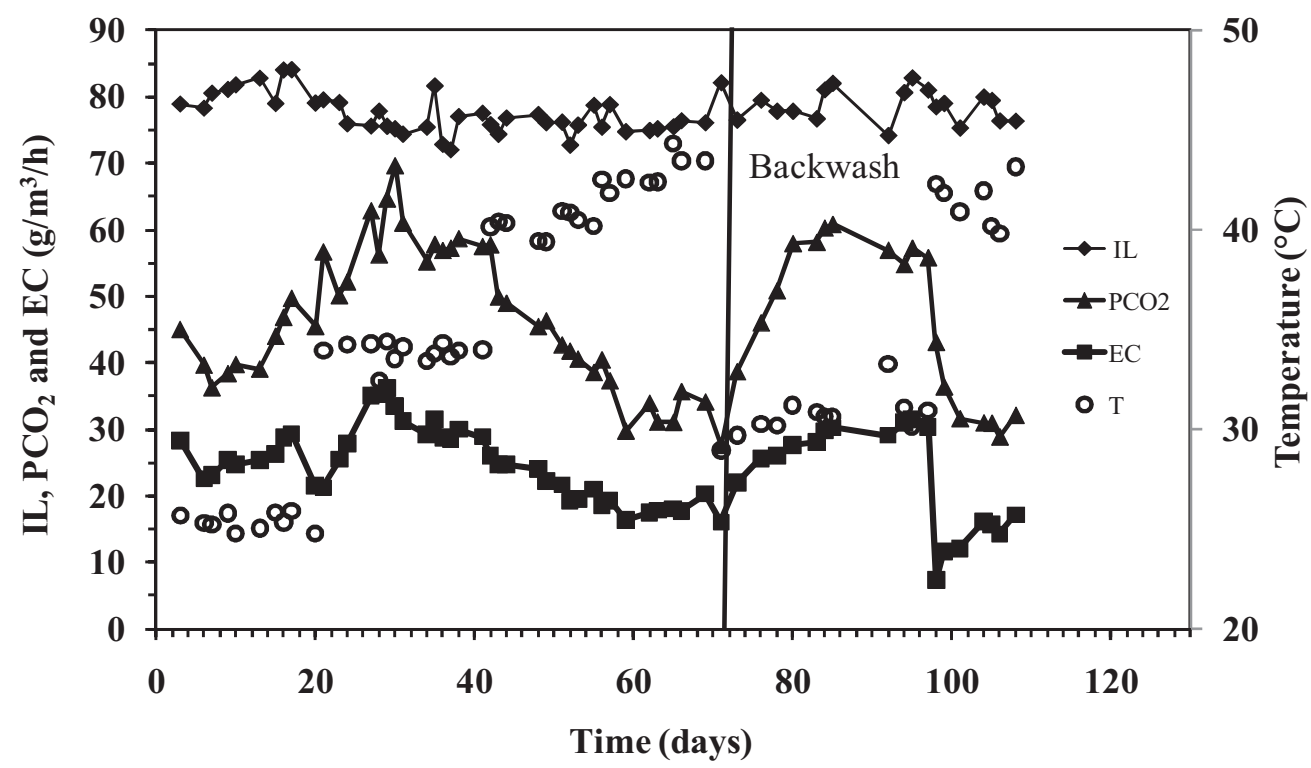

Figure 2: Inlet load (IL), carbon dioxide production rate $\left(\mathrm{PCO}_{2}\right)$, elimination capacity (EC) and temperature $(\mathrm{T})$ as a function of time for $\mathrm{BFH}$.

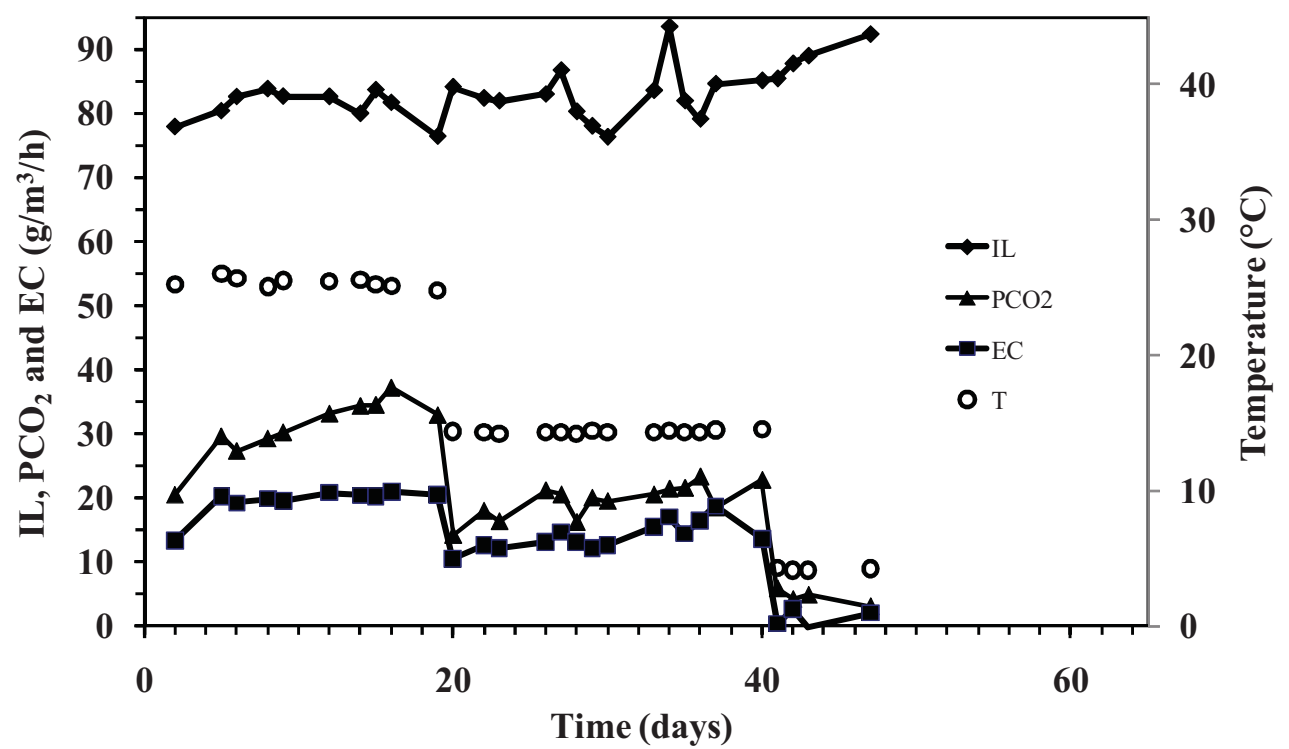

Figure 3: Inlet load (IL), carbon dioxide production rate $\left(\mathrm{PCO}_{2}\right)$, elimination capacity (EC) and temperature $(\mathrm{T})$ as a function of time for BFL. 
Both BFH and BFL were operated under the ambient room temperature of $24^{\circ} \mathrm{C}$ during the first 20-day period. The average measured temperature inside the filter bed was $25.4^{\circ} \mathrm{C}$. From day 20 to 40 , the average temperatures were $33.6^{\circ} \mathrm{C}$ and $14.3^{\circ} \mathrm{C}$ for $\mathrm{BFH}$ and BFL, respectively. BFH was operated for 15 days at $40.3^{\circ} \mathrm{C}$ and 14 days at $42.9^{\circ} \mathrm{C}$, while BFL was operated one more week at $4.2^{\circ} \mathrm{C}$. To confirm the optimal range of temperature, $\mathrm{BFH}$ was operated for 27 days more at $31.1^{\circ} \mathrm{C}$ after a backwash of the biofilter. The temperature was then increased to $41.5^{\circ} \mathrm{C}$ during 10 days.

At ambient temperature $\left(24^{\circ} \mathrm{C}\right)$, the EC averaged $23 \pm 2 \mathrm{~g} \mathrm{CH}_{4} / \mathrm{m}^{3} / \mathrm{h}$ for BFH and BFL. At $33.6^{\circ} \mathrm{C}$, the EC reached a plateau of $30 \pm 1 \mathrm{~g} \mathrm{CH}_{4} / \mathrm{m}^{3} / \mathrm{h}$. For temperatures higher than $34^{\circ} \mathrm{C}$, the $\mathrm{EC}$ decreased with temperature. At $40.3^{\circ} \mathrm{C}$, the EC varied from 26 to $21 \mathrm{~g} \mathrm{CH}_{4} / \mathrm{m}^{3} / \mathrm{h}$ and it remained constant at $18 \pm$ $1 \mathrm{~g} \mathrm{CH}_{4} / \mathrm{m}^{3} / \mathrm{h}$ for 14 days at $42.9^{\circ} \mathrm{C}$. After the backwash of the biofilter, the EC reached a value similar to the one at $33.6^{\circ} \mathrm{C}$. These results confirmed that the optimal temperature range was from $31^{\circ} \mathrm{C}$ to $34^{\circ} \mathrm{C}$. Increasing the temperature by steps of $10^{\circ} \mathrm{C}$ resulted in a decrease of biofilter performance with a drop in $\mathrm{EC}$ to $7 \mathrm{~g} \mathrm{CH}_{4} / \mathrm{m}^{3} / \mathrm{h}$ at $41.5^{\circ} \mathrm{C}$ and then a stabilization at $14 \pm 4 \mathrm{~g} \mathrm{CH}_{4} / \mathrm{m}^{3} / \mathrm{h}$ which resembled the previous results at $42.9^{\circ} \mathrm{C}$.

The decrease in temperature had a negative effect on BFL's performance. The first temperature drop from $24^{\circ} \mathrm{C}$ to $14.3^{\circ} \mathrm{C}$ resulted in a decrease of the EC from $23 \pm 2$ to $14 \pm 4 \mathrm{~g} \mathrm{CH}_{4} / \mathrm{m}^{3} / \mathrm{h}$. From $14.3^{\circ} \mathrm{C}$ to $4.2^{\circ} \mathrm{C}$, BFL showed nearly a complete inhibition of $\mathrm{CH}_{4}$ oxidation with an $\mathrm{EC}$ of $1.2 \pm$ $1.4 \mathrm{~g} \mathrm{CH}_{4} / \mathrm{m}^{3} / \mathrm{h}$.

The $\mathrm{CO}_{2}$ production rate followed the $\mathrm{EC}$ trend with high values up to $58 \pm 5 \mathrm{~g} \mathrm{CO}_{2} / \mathrm{m}^{3} / \mathrm{h}$ at $33.6^{\circ} \mathrm{C}$ and low ones of $4 \pm 1 \mathrm{~g} \mathrm{CO}_{2} / \mathrm{m}^{3} / \mathrm{h}$ at $4.2^{\circ} \mathrm{C}$. The decrease in temperature by steps of $10^{\circ} \mathrm{C}$ implied a drastic change of operating conditions. The degrading bacteria were still able to remove $\mathrm{CH}_{4}$ at $14.3^{\circ} \mathrm{C}$ with a conversion of $17 \pm 2 \%$ but when the temperature dropped to $4^{\circ} \mathrm{C}$, conversion was as low as $1 \pm 2 \%$. Complete inhibition at low temperatures has already been reported by several authors [13, 31]. Reversely, no inhibition was noticed when the temperature was increased with a conversion of $30 \pm 3 \%$ and $24 \pm 1 \%$ for $40.3^{\circ} \mathrm{C}$ and $42.9^{\circ} \mathrm{C}$, respectively. Temperatures higher than $45^{\circ} \mathrm{C}$ were not studied due to reasons of laboratory safety. Furthermore, this temperature has already been shown to inhibit $\mathrm{CH}_{4}$ oxidation $[13,32]$.

This response to temperature results from the type of microorganisms responsible for $\mathrm{CH}_{4}$ degradation. As it was shown in a previous study, Methylocystis parvus appeared to be the dominant $\mathrm{CH}_{4}$-degrading bacteria in a biofilter used to treat $\mathrm{CH}_{4}$ [21]. This bacteria is mesophilic with an optimal range of temperature for growth between $23-25^{\circ} \mathrm{C}$ and $31-34^{\circ} \mathrm{C}$ [33].

The values of pressure drop $(\Delta \mathrm{P})$ for $\mathrm{BFH}$ and BFL are presented in Table 2 . The initial $\Delta \mathrm{P}$ was similar for the two biofilters at $0.04 \mathrm{~cm} \mathrm{H}_{2} \mathrm{O} / \mathrm{m}$. At day 47 , BFL had a final $\Delta \mathrm{P}$ of $0.07 \mathrm{~cm} \mathrm{H}_{2} \mathrm{O} / \mathrm{m}$

Table 2: Pressure drop of BFL and BFH.

\begin{tabular}{lccc}
\hline Biofilter & Period (days) & Temperature $\left({ }^{\circ} \mathrm{C}\right)$ & Total $\Delta \mathrm{P}\left(\mathrm{cm} \mathrm{H}_{2} \mathrm{O} / \mathrm{m}\right)$ \\
\hline BFH & $1-20$ & 25.4 & 0.04 \\
& $21-41$ & 33.6 & $0.04-0.05$ \\
& $42-55$ & 40.3 & $0.05-0.08$ \\
(backwash) & $56-69$ & 42.9 & $0.09-0.11$ \\
& $70-97$ & 31.1 & $0.13-0.3$ \\
BFL & $98-108$ & 41.5 & $0.5-0.7$ \\
& $1-19$ & 25.4 & 0.04 \\
& $20-40$ & 14.3 & $0.04-0.06$ \\
\hline
\end{tabular}


and at day $69, \mathrm{BFH}$ 's $\Delta \mathrm{P}$ was $0.11 \mathrm{~cm} \mathrm{H}_{2} \mathrm{O} / \mathrm{m}$. These values of $\Delta \mathrm{P}$ are low but $\mathrm{BFH}$ was backwashed on day 69 because of a high amount of biomass visible in the biofilter. After the backwash, the values of $\Delta \mathrm{P}$ are higher because of water accumulation in the biofilter. The backwash procedure used in this study consisted of pouring tap water $(\sim 4 \mathrm{~L})$ in each of the three biofilter sections individually. However, the $10^{\circ} \mathrm{C}$ temperature increase at day 98 may have killed a significant amount of biomass by thermal denaturation, therefore increasing BFH's $\Delta \mathrm{P}$ from $0.5 \mathrm{~cm} \mathrm{H}_{2} \mathrm{O} / \mathrm{m}$ to $0.7 \mathrm{~cm} \mathrm{H}_{2} \mathrm{O} / \mathrm{m}$.

\subsubsection{Quantification of the effect of temperature}

Figure 4 presents the experimental data of the EC as a function of temperature and the models. The coefficients for the Arrhenius type model and the Esener type model are given in Table 3 . The determination coefficients obtained for the Arrhenius $\left(14-34^{\circ} \mathrm{C}\right)$ and Esener $\left(4-41^{\circ} \mathrm{C}\right)$ models fitted to experimental data were 0.972 and 0.975 , respectively. From $14^{\circ} \mathrm{C}$ to $34^{\circ} \mathrm{C}$, the $\mathrm{EC}$ followed an exponential trend as

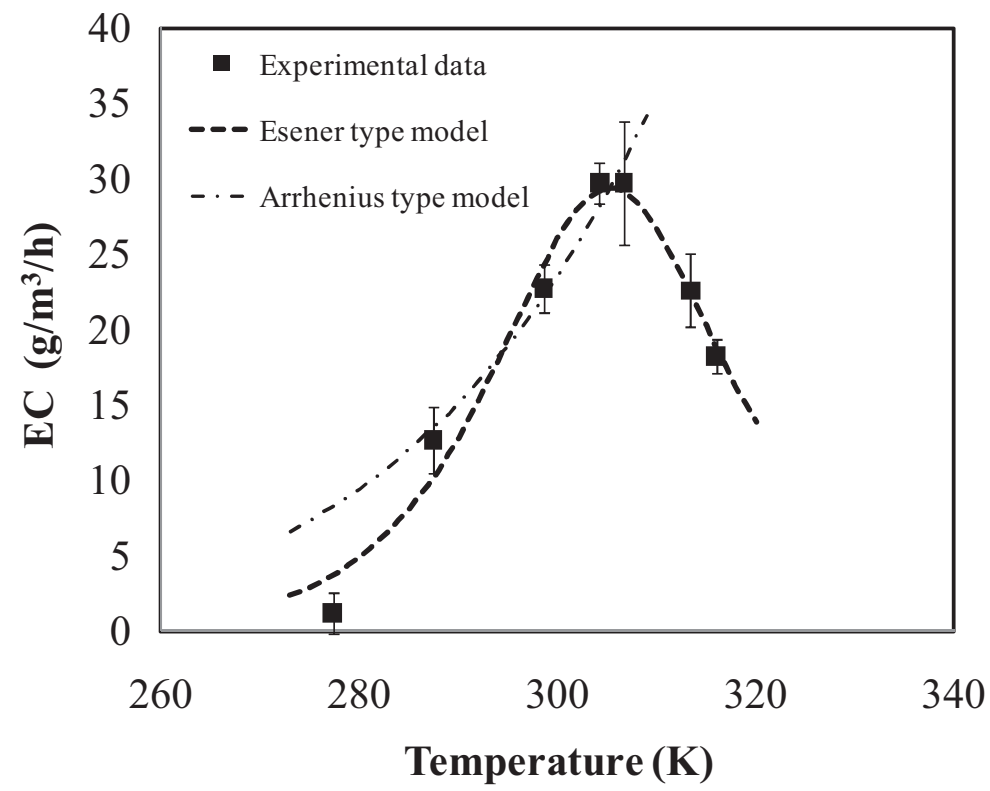

Figure 4: Effect of temperature on elimination capacity (EC) on methane in an inorganic biofilter.

Table 3: Temperature coefficients for Arrhenius and Esener models.

\begin{tabular}{lc}
\hline Coefficients & \\
\hline $\mathrm{A}, \mathrm{g} / \mathrm{m}^{3} / \mathrm{h}$ & $8.5 \mathrm{E}+6$ \\
$\mathrm{E}_{\mathrm{a}}, \mathrm{kJ} / \mathrm{mol}$ & 32 \\
$\mathrm{~A}^{\prime}, \mathrm{g} / \mathrm{m}^{3} / \mathrm{h}$ & $1.6 \mathrm{E}+13$ \\
$\mathrm{k}(-)$ & $1.7 \mathrm{E}+25$ \\
$\mathrm{E}_{1}, \mathrm{~kJ} / \mathrm{mol}$ & 67 \\
$\mathrm{E}_{2}, \mathrm{~kJ} / \mathrm{mol}$ & 148 \\
\hline
\end{tabular}


predicted by the Arrhenius equation. However, the EC decreased after reaching the $T_{o p t}$ in the biofilter. The $T_{o p t}$ calculated from eqn (7) was $32^{\circ} \mathrm{C}$. This value lies within a typical range for mesophilic microorganisms $[10,13,14]$ and it was in the optimal range of temperature observed experimentally from $31^{\circ} \mathrm{C}$ to $34^{\circ} \mathrm{C}$.

The results of the Esener type model are significant according to a $t$-test with a $t$ value of 14 in a confidence interval of $95 \%(n=7)$, as are the results of the Arrhenius type model with a $t$ of 13 in the same confidence interval $(n=4)$.

The activation energy is generally underestimated with the use of the Arrhenius type model [25] which is consistent with the values presented in Table 3 where $\mathrm{E}_{\mathrm{a}}=32 \mathrm{~kJ} / \mathrm{mol}<\mathrm{E}_{1}=67 \mathrm{~kJ} / \mathrm{mol}$. The Esener model introduces a term which predicts the decrease of the macrokinetic parameter after $T_{\text {opt }}$. In fact, $E_{2}$ is defined as the activation energy for thermal denaturation and is generally higher than the activation energy for growth [34]. In our case, $\mathrm{E}_{2}$ is two times higher than $\mathrm{E}_{1}$. For comparison, Gebert et al. have calculated an energy activation of $74.5 \mathrm{~kJ} / \mathrm{mol}$ for $\mathrm{CH}_{4}$ oxidation in a biofilter for a temperature rise from $10^{\circ} \mathrm{C}$ to $20^{\circ} \mathrm{C}$ [17].

\subsection{Experiment on the amount of nutrient solution}

Figure 5 presents the EC and the amount of NS for an IL of $80 \pm 2 \mathrm{~g} \mathrm{CH}_{4} / \mathrm{m}^{3} / \mathrm{h}$. A period of adaptation was noticed from day 1 to day 14 with a maximum EC of $29 \pm 1 \mathrm{~g} \mathrm{CH}_{4} / \mathrm{m}^{3} / \mathrm{h}$. Decreasing the amount of NS from $101 \mathrm{~L}_{\mathrm{NS}} / \mathrm{m}^{3}{ }_{\mathrm{v} \text { bed }} / \mathrm{d}$ to $34 \mathrm{~L}_{\mathrm{NS}} / \mathrm{m}^{3}{ }_{\mathrm{v} \text { bed }} / \mathrm{d}$ had no visible effect on biofilter performance. The EC remained constant around $23 \pm 1 \mathrm{~g} \mathrm{CH}_{4} / \mathrm{m}^{3} / \mathrm{h}$. Reducing the amount of NS to $17 \mathrm{~L}_{\mathrm{NS}} / \mathrm{m}^{3}$ V bed $/ \mathrm{d}$ induced a decrease of the EC to $17 \pm 3 \mathrm{~g} \mathrm{CH}_{4} / \mathrm{m}^{3} / \mathrm{h}$.

No important increase in the $\mathrm{P}$ was noticed when the amount of NS was decreased from $101 \mathrm{~L}_{\mathrm{NS}} / \mathrm{m}^{3}{ }_{\mathrm{V} \text { bed }} / \mathrm{d}$ to $34 \mathrm{~L}_{\mathrm{NS}} / \mathrm{m}^{3}{ }_{\mathrm{V} \text { bed }} / \mathrm{d}$ with $0.09 \mathrm{~cm} \mathrm{H}_{2} \mathrm{O} / \mathrm{m}$ and $0.14 \mathrm{~cm} \mathrm{H}_{2} \mathrm{O} / \mathrm{m}$ at the end of each period, respectively. After the backwash of the biofilter on day 56 , the $\mathrm{P}$ at $17 \mathrm{~L}_{\mathrm{NS}} / \mathrm{m}^{3}{ }_{\mathrm{V} \text { bed }} / \mathrm{d}$ has decreased to $0.04 \mathrm{~cm} \mathrm{H}_{2} \mathrm{O} / \mathrm{m}$.

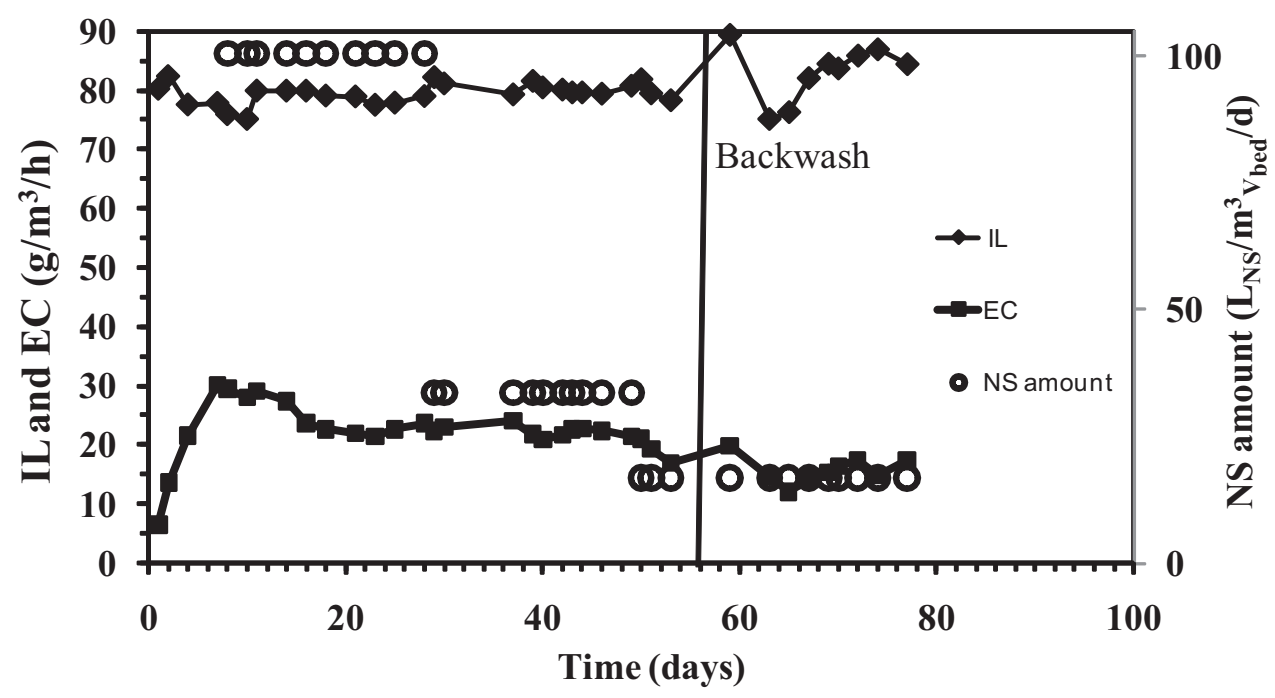

Figure 5: Inlet load (IL), elimination capacity (EC) and nutrient solution (NS) amount as a function of time for BFA. 
The moisture content of each biofilter section was measured at the three NS flow rates. While it averaged 36\% (water/filter bed sample, w/w) for the three sections for both $101 \mathrm{~L}_{\mathrm{NS}} / \mathrm{m}^{3} \mathrm{v}$ bed $/ \mathrm{d}$ and 34 $\mathrm{L}_{\mathrm{NS}} / \mathrm{m}^{3}{ }_{\mathrm{V} \text { bed }} / \mathrm{d}$, it decreased to $27 \%$ at $17 \mathrm{~L}_{\mathrm{NS}} / \mathrm{m}^{3}{ }_{\mathrm{V} \text { bed }} / \mathrm{d}$.

A NS is necessary due to the use of an inorganic filter bed. No water accumulation was observed in the top section of the biofilter which could explain the low $\Delta \mathrm{P}$. On the other hand, the $\mathrm{CH}_{4}$ conversion decreased by $33 \%$ in the bottom section when the amount of NS was reduced from $34 \mathrm{~L}_{\mathrm{NS}} / \mathrm{m}^{3}{ }_{\mathrm{V} \text { bed }} / \mathrm{d}$ to $17 \mathrm{~L}_{\mathrm{NS}} / \mathrm{m}^{3}{ }_{\mathrm{V} \text { bed }} / \mathrm{d}$. No drying-out of the filter bed was observed. However, it may be hypothesized that the nutrient uptake is higher in the top section and therefore deprived the bottom section from the micro and macronutrients. Considering these details, a minimal amount of NS of $34 \mathrm{~L}_{\mathrm{NS}} / \mathrm{m}^{3} \mathrm{v \text {bed }} / \mathrm{d}$ is required as there will be an optimal distribution of the NS and no water accumulation along the biofilter.

\subsection{Experiment on the concentration of carbon dioxide}

Figure 6 presents the IL, $\mathrm{PCO}_{2}, \mathrm{EC}$ and $\mathrm{CO}_{2}$ concentration as a function of time for BFC. The IL was fixed at $73 \pm 2 \mathrm{~g} \mathrm{CH}_{4} / \mathrm{m}^{3} / \mathrm{h}$. The biofilter was operated during 99 days and no variation of the $\mathrm{EC}$ was noticed with $18 \pm 1 \mathrm{~g} \mathrm{CH}_{4} / \mathrm{m}^{3} / \mathrm{h}$ for $\mathrm{CO}_{2}$ concentrations varying from 650 to $18,500 \mathrm{ppmv}$. These results are coherent with previous experiments in the literature where no effect was visible in $\mathrm{CH}_{4}$ oxidation rates for $\mathrm{CO}_{2}$ concentrations varying from 400 to $400,000 \mathrm{ppmv}$ in landfill cover soils [23]. The results are different from the experiments led on forest soil where the $\mathrm{CH}_{4}$ consumption rate was reduced by $30 \%$ for a $\mathrm{CO}_{2}$ concentration 200 ppmv higher than the atmospheric concentration (400 ppmv) [22].

$\mathrm{CO}_{2}$ concentrations in forest soils are generally lower $(0.04 \%, \mathrm{v} / \mathrm{v})$ than in landfill soils $(30-65 \%$, v/v) $[6,8,22]$. It may be hypothesized that methanotrophs from forest soils would be more affected by variations in $\mathrm{CO}_{2}$ concentrations than the methanotrophs responsible for $\mathrm{CH}_{4}$ degradation in landfill soils.

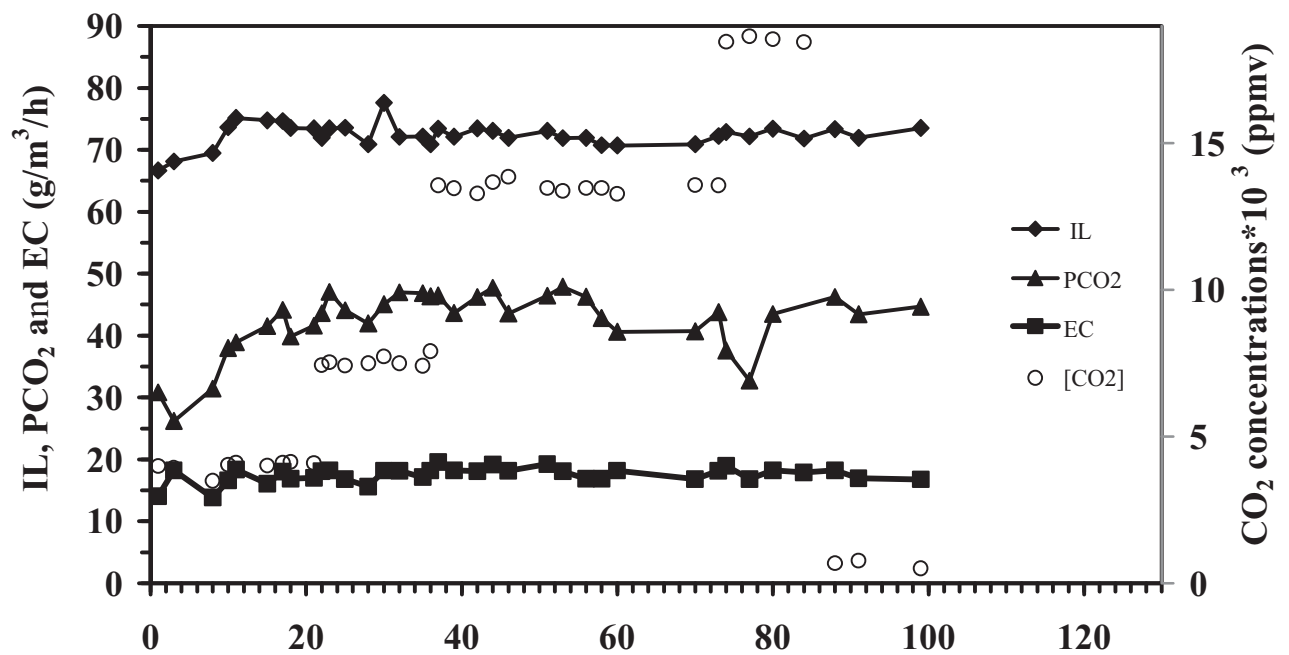

Time (days)

Figure 6: Inlet load (IL), elimination capacity (EC), carbon dioxide production rate $\left(\mathrm{PCO}_{2}\right)$ and $\mathrm{CO}_{2}$ concentrations as a function of time for BFC. 


\section{CONCLUSION}

The main objective of this study was to evaluate the effect of the temperature on $\mathrm{CH}_{4}$ removal by biofiltration. Eight temperatures were tested from $4^{\circ} \mathrm{C}$ to $43^{\circ} \mathrm{C}$. The effect of the temperature was well quantified, thanks to the modified Esener model. From this model, the optimum temperature calculated was $32^{\circ} \mathrm{C}$ which was in the range observed experimentally. At this temperature, the highest EC was observed with an average of $30 \pm 1 \mathrm{~g} \mathrm{CH}_{4} / \mathrm{m}^{3} / \mathrm{h}$ for an $\mathrm{IL}$ of $80 \pm 5 \mathrm{~g} \mathrm{CH}_{4} / \mathrm{m}^{3} / \mathrm{h}$. The decrease of the amount of NS from $101 \mathrm{~L}_{\mathrm{NS}} / \mathrm{m}^{3}{ }_{\mathrm{V} \text { bed }} / \mathrm{d}$ to $34 \mathrm{~L}_{\mathrm{NS}} / \mathrm{m}^{3} \mathrm{~V}$ bed $/ \mathrm{d}$ appeared to have no effect on the EC. However, at $17 \mathrm{~L}_{\mathrm{NS}} / \mathrm{m}^{3}{ }_{\mathrm{V} \text { bed }} / \mathrm{d}$, a decrease of the EC was observed at $17 \pm 3 \mathrm{~g} \mathrm{CH}_{4} / \mathrm{m}^{3} / \mathrm{h}$. A minimal amount of NS of $34 \mathrm{~L}_{\mathrm{NS}} / \mathrm{m}^{3} \mathrm{v}$ bed $/ \mathrm{d}$ should be added to the biofilter to ensure an equal distribution of the NS. The study regarding $\mathrm{CO}_{2}$ concentrations varying from 650 to $18,500 \mathrm{ppmv}$ showed no effect on the EC which remained constant at $18 \pm 1 \mathrm{~g} \mathrm{CH}_{4} / \mathrm{m}^{3} / \mathrm{h}$.

The results obtained in this study highlight the importance of both the temperature and the amount of NS for an inorganic based-bed biofilter and may have to be taken into consideration in landfill management. Landfills are open-space operated and undergo high temperature variations annually. Because of the decrease in microorganism activity under $14^{\circ} \mathrm{C}$, it is essential to design the biofilter adequately in anticipation of the cold season to maintain a minimal temperature in filter bed and ensure the microbial degradation of $\mathrm{CH}_{4}$. Although the objective would be to remain at the optimum temperature, it should be noted that microbial activity could be sustained even during the cold season. Furthermore, an appropriate way to spray the NS has to be installed to promote a good homogeneity of nutrient supply in the filter bed and also to control the supply flow rate to minimize either the drying-out or water clogging phenomena. Finally, the range of $\mathrm{CO}_{2}$ concentrations tested did not show any inhibition of $\mathrm{CH}_{4}$ oxidation. However, higher concentrations of $\mathrm{CO}_{2}$ should be tested at a pilot scale to confirm this trend for real situations.

\section{ACKNOWLEDGEMENTS}

This work was supported by a Strategic grant from the Natural Sciences and Engineering Council of Canada to Michèle Heitz in partnership with le Centre de Recherche Industrielle du Québec and Viaporc Inc. and by a Discovery grant from the Natural Sciences and Engineering Council of Canada to Michèle Heitz. The authors are also thankful to Matthieu Girard, PhD student in chemical engineering and biotechnological engineering, for English text revision.

\section{REFERENCES}

[1] Leigh Mascarelli, A., A sleeping giant? Nature, 3, pp. 46-49, 2009.

[2] Olivier, J.J.M. \& Berdowski, J.G.J., Global Emission Sources and Sinks, The Climate System, A.A. Balkama Publishers, 2001.

[3] Solomon, S., Qin, D., Manning, M., Alley, R.B., Berntsen, T., Bindoff, N.L., Chen, Z., Chidthaisong, A., Gregory, J.M., Hegerl, G.C., Heimann, M., Hewitson, B., Hoskins, B.J., Joos, F., Jouzel, J., Kattsov, V., Lohmann, U., Matsuno, T., Molina, M., Nicholls, N., Overpeck, J., Raga, G., Ramaswamy, V., Ren, J., Rusticucci, M., Somerville, R., Stocker, T.F., Whetton, P., Wood, R.A. \& Wratt, D., Contribution of Working Group I to the Fourth Assessment Report of the Intergovernmental Panel on Climate Change, Cambridge University Press: Cambridge, United Kingdom and New York, NY, USA, 2007.

[4] Environnement Canada, Sources et puits de gaz à effet de serre au Canada. Rapport d'inventaire national 1990-2007. Sources et puits de gaz à effet de serre au Canada. 978-1-100-12999-0, pp. 1-747, 2009. 
[5] Bogner, J., Abdelrafie Ahmed, M., Diaz, C., Faaij, A., Gao, Q., Hashimoto, S., Mareckova, K., Pipatti, R. \& Zhang, T., Waste Management, In Climate Change 2007: Mitigation. Contribution of Working Group III to the Fourth Assessment Report of the Intergovernmental Panel on Climate Change, Chapter 10, Cambridge University Press: Cambridge, United Kingdom and New York, NY, USA, pp. 585-618, 2007.

[6] Spokas, K., Bogner, J., Chanton, J.P., Morcet, M., Aran, C., Graff, C., Golvan, Y.M. \& Hebe, I., Methane mass balance at three landfill sites: what is the efficiency of capture by gas collection systems? Waste Management, 26(5), pp. 516-525, 2006. doi:http://dx.doi.org/10.1016/j. wasman.2005.07.021

[7] Haubrichs, R. \& Widmann, R., Evaluation of aerated biofilter systems for microbial methane oxidation of poor landfill gas. Waste Management, 26(4), pp. 408-416, 2006. doi:http://dx.doi. org/10.1016/j.wasman.2005.11.008

[8] Scheutz, C., Kjeldsen, P., Bogner, J.E., De Visscher, A., Gebert, J., Hilger, H.A., Huber-Humer, M. \& Spokas, K., Microbial methane oxidation processes and technologies for mitigation of landfill gas emissions. Waste Management and Research, 27(5), pp. 409-455, 2009. doi:http://dx.doi.org/10.1177/0734242X09339325

[9] Hanson, R. \& Hanson, T., Methanotrophic bacteria. Microbiological Reviews, 60(2), pp. 439-471, 1996.

[10] Humer, M. \& Lechner, P., Alternative approach to the elimination of greenhouse gases from old landfills. Waste Management and Research, 17(6), pp. 443-452, 1999.

[11] Zeiss, C.A., Accelerated methane oxidation cover system to reduce greenhouse gas emissions from MSW landfills in cold, semi-arid regions. Water, Air, and Soil Pollution, 176(1-4), pp. 285-306, 2006.

[12] Scheutz, C. \& Kjeldsen, P., Environmental factors influencing attenuation of methane and hydrochlorofluorocarbons in landfill cover soils. Journal of Environmental Quality, 33(1), pp. 72-79, 2004. doi:http://dx.doi.org/10.2134/jeq2004.0072

[13] Visvanathan, C., Pokhrel, D., Cheimchaisri, W., Hettiaratchi, J.P.A. \& Wu, J.S., Methanotrophic activities in tropical landfill cover soils: effects of temperature, moisture content and methane concentration. Waste Management and Research, 17(4), pp. 313-323, 1999.

[14] Park, S., Lee, C., Ryu, C. \& Sung, K., Biofiltration for reducing methane emissions from modern sanitary landfills at the low methane generation stage. Water, Air, and Soil Pollution, 196(1-4), pp. 19-27, 2009.

[15] Einola, J.-M., Sormunen, K.M. \& Rintala, J.A., Methane oxidation in a boreal climate in an experimental landfill cover composed from mechanically-biologically treated waste. Science of the Total Environment, 407(1), pp. 67-83, 2008. doi:http://dx.doi.org/10.1016/ j.scitotenv.2008.08.016

[16] Mudliar, S., Giri, B., Padoley, K., Satpute, D., Dixit, R., Bhatt, P., Pandey, R., Juwarkar, A. \& Vaidya, A., Bioreactors for treatment of VOCs and odours - a review. Journal of Environmental Management, 91(5), pp. 1039-1054, 2010.

[17] Gebert, J., Groengroeft, A. \& Miehlich, G., Kinetics of microbial landfill methane oxidation in biofilters. Waste Management, 23(7), pp. 609-619, 2003. doi:http://dx.doi.org/10.1016/ $\underline{\text { S0956-053X(03)00105-3 }}$

[18] Kallistova, A.Y., Kevbrina, M.V., Nekrasova, V.K., Shnyrev, N.A., Einola, J.M., Kulomaa, M.S., Rintala, J.A. \& Nozhevnikova, A.N., Enumeration of methanotrophic bacteria in the cover soil of an aged municipal landfill. Microbial Ecology, 54(4), pp. 637-645, 2007. doi:http://dx.doi. org/10.1007/s00248-007-9219-0 
[19] Maestre, J.P., Gamisans, X., Gabriel, D. \& Lafuente, J., Fungal biofilters for toluene biofiltration: evaluation of the performance with four packing materials under different operating conditions. Chemosphere, 67(4), pp. 684-692, 2007. doi:http://dx.doi.org/10.1016/ j.chemosphere.2006.11.004

[20] Leson, G. \& Winer, A., Biofiltration - an innovative Air-Pollution Control Technology for VOC emissions. Journal of the Air \& Waste Management Association, 41(8), pp. 1045-1054, 1991.

[21] Nikiema, J., Bibeau, L., Lavoie, J., Brzezinski, R., Vigneux, J. \& Heitz, M., Biofiltration of methane: an experimental study. Chemical Engineering Journal, 113(2-3), pp. 111-117, 2005.

[22] Phillips, R.L., Whalen, S.C. \& Schlesinger, W.H., Influence of atmospheric $\mathrm{CO}_{2}$ enrichment on methane consumption in a temperate forest soil. Global Change Biology, 7(5), pp. 557-563, 2001. doi:http://dx.doi.org/10.1046/j.1354-1013.2001.00432.x

[23] Spokas, K.A. \& Bogner, J.E., Limits and dynamics of methane oxidation in landfill cover soils. Waste Management, 2010.

[24] Alagappan, G. \& Cowan, R.M., Effect of temperature and dissolved oxygen on the growth kinetics of Pseudomonas putida F1 growing on benzene and toluene. Chemosphere, 54(8), pp. 1255-1265, 2004.

[25] Esener, A.A., Roels, J.A. \& Kossen, N.W.F., The influence of temperature on the maximum specific growth rate of Klebsiella pneumoniae. Biotechnology and Bioengineering, 23, pp. 1401-1405, 1981. doi:http://dx.doi.org/10.1002/bit.260230620

[26] Streese, J., Schlegelmilch, M., Heining, K. \& Stegmann, R., A macrokinetic model for dimensioning of biofilters for VOC and odour treatment. Waste Management, 25(9), pp. 965-974, 2005. doi:http://dx.doi.org/10.1016/j.wasman.2005.07.009

[27] Sologar, V.S., Lu, Z. \& Allen, D.G., Biofiltration of concentrated mixtures of hydrogen sulfide and methanol. Environmental Progress, 22(2), pp. 129-136, 2003. doi:http://dx.doi. org/10.1002/ep.670220215

[28] Avalos Ramirez, A., Benard, S., Giroir-Fendler, A., Jones, J.P. \& Heitz, M., Kinetics of microbial growth and biodegradation of methanol and toluene in biofilters and an analysis of the energetic indicators. Journal of Biotechnology, 138(3-4), pp. 88-95, 2008.

[29] Arrhenius, S., Über die Reaktionsgeschwingdigkeit bei der Inversion von Rohrzucker durch Säuren. Zeitschrift fur Physikalische Chemie, 4, pp. 226-248, 1889.

[30] Esener, A.A., An Engineering Study of Bacterial Kinetics and Energetics, Delft University Press, 1981.

[31] Nesbit, S. \& Breitenbeck, G., A laboratory study of factors influencing methane uptake by soils. Agriculture Ecosystems \& Environment, 41(1), pp. 39-54, 1992. doi:http://dx.doi. org/10.1016/0167-8809(92)90178-E

[32] Whalen, S.C., Reeburgh, W.S. \& Sandbeck, K.A., Rapid methane oxidation in a landfill cover soil. Applied and Environmental Microbiology, 56, pp. 3405-3411, 1990.

[33] Nozhevnikova, A.N., Nekrasova, V.K., Kevbrina, M.V. \& Kotsyurbenko, O.R., Production and oxidation of methane at low temperature by the microbial population of municipal sludge checks situated in north-east Europe. Water Science and Technology, 44(4), pp. 89-95, 2001.

[34] de Ory, I., Romero, L.E. \& Cantero, D., Modelling the kinetics of growth of Acetobacter aceti in discontinuous culture: influence of the temperature of operation. Applied Microbiology and Biotechnology, 49(2), pp. 189-193, 1998. doi:http://dx.doi.org/10.1007/s002530051157 